\title{
Patient with transient left ventricular apical ballooning and essential thrombocythemia
}

\author{
Przemijające zaburzenia kurczliwości koniuszka lewej komory u pacjenta z nadpłytkowością \\ samoistną
}

\section{Konrad Kaaz, Monika Przewłocka-Kosmala, Jacek Gajek, Andrzej Mysiak}

Chair and Department of Cardiology, Wroclaw Medical University, Poland

Post Kardiol Interw 2011; 7, 4 (26): 317-319

DOI: $10.5114 /$ pwki.2011.25792

\begin{abstract}
Tako-tsubo syndrome imitates acute myocardial infarction. In this article, we report a case of a 39-year-old male who presented with essential thrombocythemia and symptoms and signs of acute coronary syndrome. On the basis of clinical features and results of additional tests we recognized transient left ventricular apical ballooning.
\end{abstract}

Key words: tako-tsubo syndrome, male, essential thrombocythemia, transient left ventricular apical ballooning

\section{Streszczenie}

Zespół tako-tsubo często imituje objawy zawału mięśnia serca. W artykule przedstawiono pacjenta z objawową nadpłytkowością oraz objawami przedmiotowymi i podmiotowymi ostrego zespołu wieńcowego. Na podstawie całokształtu obrazu chorobowego rozpoznano przemijające zaburzenia kurczliwości lewej komory.

Słowa kluczowe: zespół tako-tsubo, mężczyzna, nadpłytkowość samoistna, przemijające zaburzenia kurczliwości lewej komory

\section{Introduction}

Transient apical ballooning of the left ventricle, including tako-tsubo syndrome (TTS), causes troubles in differential diagnosis of acute coronary syndrome. Pathogenesis of TTS is not clear. Stress seems to be the main risk factor because of the release of catecholamines and constriction of epicardial segments of coronary arteries and microvessels [1]. Recent studies also emphasize the role of unstable atherosclerotic plaque in the epicardial arteries and the role of nervation topography of the myocardial segments [2]. Most of the cases of transient apical ballooning described in the literature occurred in women. The dominant clinical picture includes angina-like symptoms, increased concentration of myocardial necrosis markers, ST-segment elevation and T-wave inversion on the ECG. Additionally there is hypokinesis of the apical segments and compensatory hyperkinesis of the remaining segments.
It was demonstrated that essential thrombocythemia and myeloproliferative disease of the bone marrow increase the risk of thrombotic and bleeding complications. These patients are more likely to suffer from thrombotic complications affecting coronary, cerebral and peripheral arteries and bleeding complications. The frequency of acute coronary syndromes in these patients is around 9.4\% [3].

\section{Case report}

A 39-year-old male with episodic bronchial asthma, essential thrombocythemia and a history of a 2-h long incident of transient ischaemic attack (aphasia, right-sided hemiplegia, vision impairment) reported to the Emergency Room of the Department of Cardiology with symptoms of angina which occurred after strong stress. The patient was on chronic treatment with acetylsalicylic acid $(75 \mathrm{mg} /$ day) and on sporadic treatment with salbutamol (inhalation) due to bronchial asthma. He denied the abuse of drugs

Corresponding author/Adres do korespondencji:

Konrad Kaaz MD, Chair and Department of Cardiology, Wroclaw Medical University, 213 Borowska, 50-566 Wrocław, Poland, tel.: +48 7173642 00, e-mail: konrad.kaaz@gmail.com

Praca wpłynęła: 29.06.2011, wersja poprawiona: 3.07.2011, przyjęta do druku: 26.08.2011. 
and other stimulating substances. The ECG trace showed ST-segment elevation and negative T-waves in the inferior wall leads (II, III, aVF), increased concentration of troponin I - $2.28 \mathrm{ng} / \mathrm{ml}$ (normal value $<0.1 \mathrm{ng} / \mathrm{ml}$ ) and thrombocythemia -673 ths $/ \mathrm{ml}$ (reference range $140-400$ ths $/ \mathrm{ml}$ ). There were no signs of heart failure on admission; blood pressure was 147/90 $\mathrm{mmHg}$ and heart rate was $88 \mathrm{bpm}$. The patient underwent an emergency coronary angiography which showed haemodynamically insignificant atherosclerotic changes (up to $30 \%$ of diameter) in the left anterior descending coronary artery of the left coronary artery and in the right coronary artery. Echocardiography demonstrated regional contraction abnormalities comprising the following segments: median inferior (9), apical anterior (16) and the apex (17). The patient received acetylsalicylic acid (75 mg/day), clopidogrel (75 mg/day), ramipril (2.5 mg/day), simvastatin (20 mg/day) and diltiazem (120 mg/day) due to the history of asthma. There were recurrences of chest pain during the rest of hospitalization and biochemical markers normalized. The electrocardiographic picture did not change, but control echocardiography performed on day 4 showed resolution of previously described contraction abnormalities. Laboratory tests to assess the status of the coagulation system were done: antithrombin level $114.11 \%$ (reference values $85-115 \%$ ), C-protein activity $95.95 \%$ (reference values $70-140 \%$ ), concentration of the free fraction of the S-protein $117.16 \%$ (reference values $60-115 \%$ ), platelet reactivity: collagen/EPI > $300 \mathrm{~s}$ (reference values 84-160 s) and collagen/ADP > $300 \mathrm{~s}$ (reference values 62-121 s), von Willebrand factor activity $73.3 \%$ (reference values $45-150 \%$ ). These results demonstrated effective platelet reactivity inhibition. Abdominal ultrasound showed the presence of hepatic angiomas, left nephrolithiasis, enlarged spleen and enlarged prostate. The consulting neurologist did not find any significant abnormalities including signs of acute focal CNS lesions. Magnetic resonance imaging of the brain did not disclose any acute focal lesions. There were no abnormalities in the fundoscopic examination as assessed by the ophthalmologist.

Control examinations performed after 1 month showed a persistent thrombocythemia 600 ths $/ \mathrm{ml}$ and negative T-waves in leads II, III, aVF of the ECG. Echocardiography did not demonstrate any regional contraction abnormalities.

\section{Discussion}

The presented case of transient left ventricular contraction abnormalities in a 39-year-old male with a history of a transient ischaemic attack and essential thrombocythemia may be considered as a special variant of an acute coronary syndrome [1]. Analysis of the results of additional studies and the clinical course led to the diagnosis of left ventricular apical ballooning syndrome caused by impaired blood supply. There were many symptoms which might have influenced the occurrence of this syndrome including a stressful situation at work and thrombocythemia. Tako-tsubo syndrome occurs more frequently in women, but there are case reports of this disease in men. They were related to general anaesthesia, arthroscopy, bronchoscopy, gastroscopy, urethral catheterization or to sexual activity [4]. The accessible literature includes a case report of TTS during intensive treatment of an asthmatic state with ketamine and adrenaline administration [5]. All of the states mentioned above may be related to stress reactions and particularly to the excretion of catecholamines. These potent biological substances are considered as among the key causes of TTS, which is also known as stressinduced cardiomyopathy. We found 18 cases of patients with an acute coronary syndrome and essential thrombocythemia in the literature. One third of them did not have typical changes on coronary angiography [6]. Therefore it seems important to treat thrombocythemia especially in the context of described symptoms of TTS, history of TIA and vision impairment. These kinds of patients should be qualified into the high risk group and considered for initiation of treatment focused on lowering the platelet count. Planning of the haematological therapy should include potential adverse events of phosphodiesterase III use (anagrelid) [7]. In the literature there is growing attention to patients with suspected acute coronary syndrome, increased troponin concentration and the lack of angiographic features of atherosclerosis or thrombosis in the epicardial coronary arteries. These clinical situations consist of supraventricular arrhythmias (including atrial fibrillation), systemic inflammatory reactions, chest and heart trauma, myocarditis or pericarditis, and impairment of pulmonary circulation.

Despite generally good prognosis of the left ventricular apical ballooning syndrome there are cases of sudden cardiac deaths of mainly older patients in long-term followup. The lack of uniform management schemes for patients with transient left ventricular apical ballooning, especially young, requires further studies addressing this group of patients.

\section{References}

1. Prasad A, Lerman A, Rihal C. Apical ballooning syndrome (TakoTsubo or stress cardiomyopathy): a mimic of acute myocardial infarction. Am Heart J 2008; 155: 408-417.

2. Pawłowski T, Mintz GS, Kulawik T, et al. Virtual histology intravascular ultrasound evaluation of the left anterior descending coronary artery in patients with transient left ventricular ballooning syndrome. Kardiol Pol 2010; 68: 1093-1098.

3. Rossi C, Randi ML, Zerbinati P, et al. Acute coronary disease in essential thrombocythemia and polycythemia vera. J Intern Med 1998; 244: 49-53.

4. Rostek M, Hrynkiewicz-Szymańska A, Pikto-Pietkiewicz W, et al. Cardiogenic shock secondary to the tako-tsubo syndrome in young male patient. Kardiol Pol 2010; 68: 942-945. 
5. Osuorji I, Williams C, Hessney J, et al. Acute stress cardiomyopathy following treatment of status asthmaticus. South Med J 2009; 102: 301-303.

6. Kumagai N, Mitsutake R, Miura S, et al. Acute coronary syndrome associated with essential thrombocythemia. J Cardiol 2009; 54: 485-489.

7. Proietti R, Rognoni A, Ardizzone F, et al. Atypical Takotsubo syndrome during anagrelide therapy. J Cardiovasc Med (Hagerstown) 2009; 10: 546-549. 